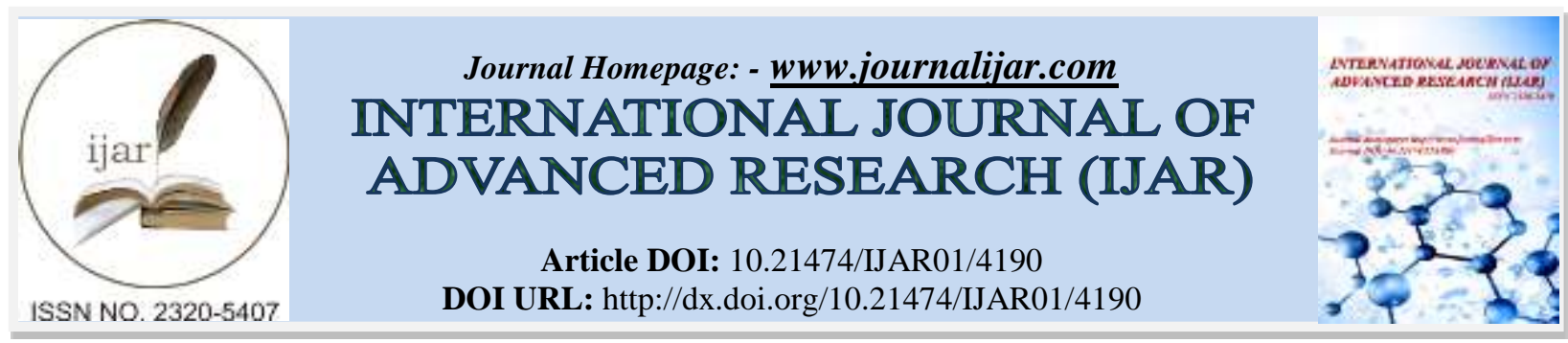

RESEARCH ARTICLE

\title{
CUSTOMERS' ATTITUDE TOWARDS ISLAMIC AND CONVENTIONAL BANK: A GLIMPSE FROM HYDERABAD, PAKISTAN.
}

\author{
Tayyaba Rafique Makhdoom ${ }^{1}$, Dr. Muhammad Nawaz ${ }^{2}$, Dr Mushtaque Ali Jariko ${ }^{3}$, Tania Mushtaque ${ }^{4}$ and \\ Amna Asif 5 . \\ 1. Lecturer, Business Administration, University of Sindh Laar Campus Badin. \\ 2. Assistant Professor, Sindh University Laar Campus Badin. \\ 3. Assistant Professor, Business Administration, University of Sindh, Jamshoro, Pakistan. \\ 4. Lecturer at Institute of Information and Communication Technology (IICT) \\ 5. BBA student Sindh University Laar Campus Badin.
}

\section{Manuscript Info}

Manuscript History

Received: 13 March 2017

Final Accepted: 17 April 2017

Published: May 2017

Key words:-

Banking industry, Islamic, Customer's

Satisfactions, Hyderabad, Pakistan
Abstract

This study investigates and compares customer satisfaction of Islamic and conventional banks within Pakistani context. Although, various researchers have attempted to understand this phenomena. However, there is rare or no literature exploring customer satisfaction of banks within the second largest city of Sindh, Hyderabad, Pakistan.

Quantitative approach was adopted to investigate and understand customer dynamics within the context of the Hyderabad. Data was analyzed through SPSS. Data analyses conclude that customer satisfaction level is different among different customers of the different types of banking system.

Copy Right, IJAR, 2016,. All rights reserved.

\section{Introduction:-}

The Islamic banking system is based on the sharia rules derived from the Quran (Holy book of Muslims) and Sunnah (Life of Prophet Muhammad PBUH). The Islamic banking system discourages interest based banking system and offered various alternative banking for the customer for example Ijahara. Zaher and Kabir (2001). The Islamic banking system has grown in the global banking arena, particularly from the last two decades (Siddiqi, 2006).

On the contrary, the conventional banking system is based on interest and widely used and trusted around the globe. Khan, Hassan and Shahid (2008) reported that the introduction of sharia based banking system augmented over all bank industry. Furthermore, inclusion of Islamic banks in banking sector brought stability in the banking sector. Yousefi, Abizadeh and McCormick (1997) noted that although both banking system is based on different orientation, it increased level of competition among them to capture market share. These authors further explained that specialy, in Muslim countries, Islamic banks have motivated people to do business with Islamic bank.

\section{Literature Review:-}

Erol et al (2014) conducted a study to compare the performance of the Islamic banks within Turkish context. Erol et al (2014) reported that Islamic banks are performing better than commercial banks. However, Riaz et al (2014) noted that Islamic banks have not fully adopted Islamic principles within Pakistani context. Based on qualitative research Riaz et al (2014) claimed that customers of conventional banks are more satisfied as compared to Islamic 
banks. Rammal and Parker revealed (2014) that banking regulatory authorities feeling pressure to develop a balance between commercial and Islamic banking system within the Pakistani context. However, Latif et al (2016) has asserted that despite the fact that Islamic and conventional banks profitability ration is same, Islamic banks have gained trust of customers. Asdullah, and Yazdifar (2016) utilized mix method strategy to investigate dynamics of Islamic banks within Pakistani context. They reported that female customer have not shown an inclination toward Islamic banks probably due to lack of information and awareness. Furthermore, Islamic banks have used advertisement primarily backed by religious motivation and other aspects of banking business has been ignored. Beck, Demirgüç-Kunt and Merrouche, (2013) claimed that although Islamic banks are cost effective, conventional banks have acquired a major share of customer markets.

Mohsin and Aftab (2014) investigated customer attitude toward halal banking and found that religious orientation impact upon attitudes toward eservice quality of Islamic banks. Despite that facts researchers has investigated various aspects of Islamic and commercial banks, we do not know about customer satisfaction from both banking systems within the context of Hyderabad, Sindh context. This study is intended to fill that gap.

\section{Objective:-}

To find out the customer opinion towards the Islamic banks and conventional banks in Hyderabad (Pakistan) means which bank's customers are more satisfied by the facilities provided by their respective banks.

\section{Hypothesis:-}

H1: Customer's mostly prefer conventional banking system as compared Islamic banking system

Ho: Customers mostly don't prefer an Islamic banking system as compared conventional banking system.

\section{Conceptual framework:-}

\section{Islamic and conventional bank}
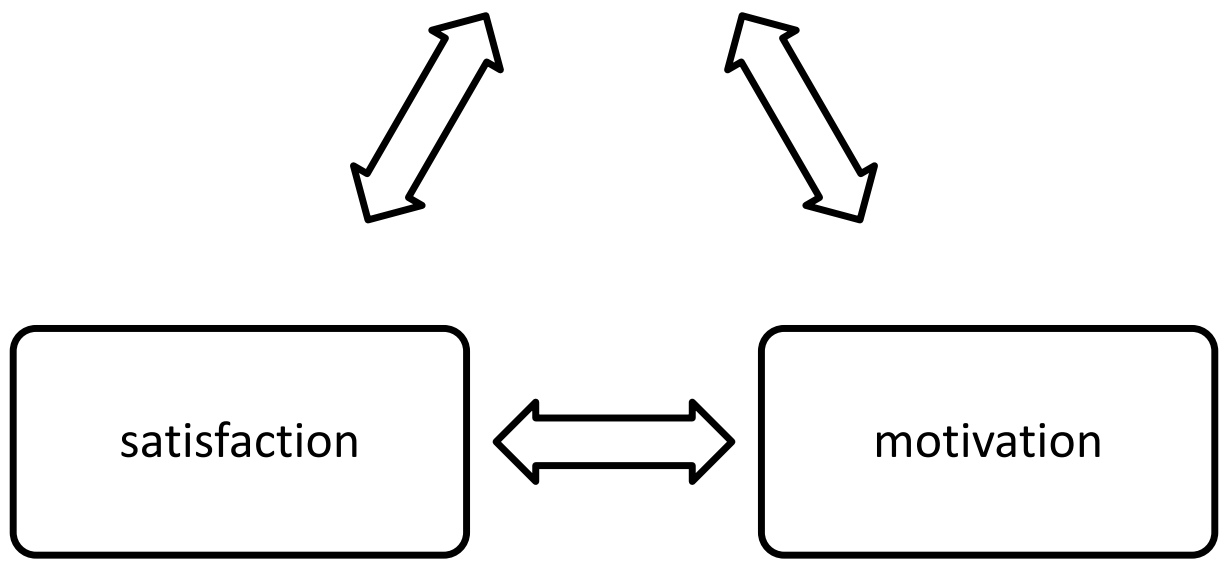

\section{Research Methodology:-}

This study evaluated the level of satisfaction of customers towards the facilities provided by the Islamic banks and the conventional banks in Hyderabad, Pakistan. The population in this study consists of all the customers of the Islamic banks and the conventional banks that are operating in Hyderabad. Sample consist of 105 customers of the banks. Random sampling technique was used. Primary data were collected with the use of a closed-ended questionnaire comprising 14 items measuring response on a nominal scale. Following is the list of banks whose customers were approached for filling out the questionnaire. 


\begin{tabular}{|l|l|l|}
\hline No. of banks & Islamic bank & Conventional bank \\
\hline Total20 & 1. Meezan Bank & 1.United Bank Ltd. \\
& 2. Bank Al-Islami & 2. Sindh Bank \\
& & 3. Allied Bank \\
& & 4. Alfalah Bank \\
& & 5. JS Bank \\
& & 6. Soneri Bank \\
& 7. Summit Bank \\
\hline
\end{tabular}

Data Analysis:-

To analysis the data we used percentage and frequency tables.

Frequency Table 1: In this table, we found the total no of customer they are divided in to two categories. One is male they are $76.2 \%$ and total no is 80 and other side is female they are totally $23.8 \%$ and their total no is 25 .

\begin{tabular}{|c|c|c|c|c|c|}
\hline \multicolumn{5}{|c|}{ Your gender? } \\
\hline \multirow{3}{*}{ Valid } & Frequency & Percent & Valid Percent & Cumulative Percent \\
\cline { 2 - 6 } & male & 80 & 76.2 & 76.2 & 76.2 \\
\cline { 2 - 6 } & female & 25 & 23.8 & 23.8 & 100.0 \\
\hline
\end{tabular}

Frequency Table 2: In this table, we found the age level of the customer. They are divided into four categories. No one is 15-30 year their total no is 47 and their percentage is 44.8\%.and second is 31-40 year their total no is 39 and their percentage is $37.1 \%$.and third is $41-50$ year their total no is 10 and their percentage is $8.6 \%$ and no four is above 51 year their total no is 9 and their percentage is $8.6 \%$.

\begin{tabular}{|c|c|c|c|c|c|}
\hline \multicolumn{9}{|c|}{ Your age? } \\
\hline \multirow{3}{*}{ Valid } & Frequency & Percent & Valid Percent & Cumulative Percent \\
\cline { 2 - 6 } & 15-30year & 47 & 44.8 & 44.8 & 44.8 \\
\cline { 2 - 7 } & 31-40year & 39 & 37.1 & 37.1 & 81.9 \\
\cline { 2 - 7 } & 41-50year & 10 & 9.5 & 9.5 & 91.4 \\
\cline { 2 - 7 } & above 51 year & 9 & 8.6 & 8.6 & 100.0 \\
\hline
\end{tabular}

Frequency Table 3: In this table we found the education level of the customer which are divided in to four categories. Number one is Intermediate their is total no is 12 and the percentage is $11.4 \%$. second is Bachelor their total no is 27 and their percentage is $25.7 \%$. Third is Master their total no is 56 and the percentage is 53.3 and the no four is other and their no is 10 and percentage is $9.5 \%$.

\begin{tabular}{|c|c|c|c|c|c|}
\hline \multicolumn{6}{|c|}{ your education? } \\
\hline \multirow{3}{*}{ Valid } & Frequency & Percent & Valid Percent & Cumulative Percent \\
\cline { 2 - 6 } & inter & 12 & 11.4 & 11.4 & 11.4 \\
\cline { 2 - 6 } & bachelor & 27 & 25.7 & 25.7 & 37.1 \\
\cline { 2 - 6 } & master & 56 & 53.3 & 53.3 & 90.5 \\
\cline { 2 - 6 } & other & 10 & 9.5 & 9.5 & 100.0 \\
\hline
\end{tabular}

Frequency Table 4: In this table, we found the different level of the profession they are divided in to four categories. Number one is Student their total no is 22. And percentage is $21.0 \%$ and number second is Employee their total no is 45 and their percentage is $42.9 \%$.and number third is Businessman their total number is 16 and their percentage is 15.2. And number four is other their total number is 22 and their percentage is 21.0 percent.

\begin{tabular}{|c|c|c|c|c|c|}
\hline \multicolumn{2}{|c|}{ Your profession? } \\
\hline \multirow{3}{*}{ Valid } & Frequency & Percent & Valid Percent & Cumulative Percent \\
\cline { 2 - 6 } & Student & 22 & 21.0 & 21.0 & 21.0 \\
\cline { 2 - 6 } & Employee & 45 & 42.9 & 42.9 & 63.8 \\
\cline { 2 - 6 } & business man & 16 & 15.2 & 15.2 & 79.0 \\
\cline { 2 - 6 } & Other & 22 & 21.0 & 21.0 & 100.0 \\
\cline { 2 - 6 } & Total & 105 & 100.0 & 100.0 & \\
\hline
\end{tabular}


Frequency Table 5: In this table we found the most important reason that attracts the customer to use Islamic banking system. They are also divided in to four categories .number one is (Religious rules and regulation) their total number of customers is 50 and their percentage is $47.6 \%$ and second is (Good services)their total number is 29 and their percentage is $27.6 \%$.and third is (Good product and policies )their total number is 15 and their percentage is $14.3 \%$ and number four is other their total number is 11 and their percentage is 10.5 .

\begin{tabular}{|c|c|c|c|c|c|}
\hline \multicolumn{6}{|c|}{$\begin{array}{l}\text { If you choose Islamic bank, what is the most important reason that attracts you to use Islamic banking } \\
\text { system? }\end{array}$} \\
\hline & & Frequency & Percent & Valid Percent & $\begin{array}{l}\text { Cumulative } \\
\text { Percent }\end{array}$ \\
\hline \multirow[t]{5}{*}{ Valid } & Religion rules and regulation & 50 & 47.6 & 47.6 & 47.6 \\
\hline & Good services & 29 & 27.6 & 27.6 & 75.2 \\
\hline & Good product and policies & 15 & 14.3 & 14.3 & 89.5 \\
\hline & Other & 11 & 10.5 & 10.5 & 100.0 \\
\hline & Total & 105 & 100.0 & 100.0 & \\
\hline
\end{tabular}

Frequency Table 6: In this table we found the most important reason of conventional bank they attract the customer to us the conventional banking system. They are divided in to four categories number one is (I want to get fixed interest) their total number is 23 and their percentage is $21.3 \%$.and second is (I already have its account) their total number is 33 and their percentage is $31.4 \%$.number third is (product and services) their total number is 40 and percentage is $38.1 \%$.and number four is (other specify) their total number is 9 and their percentage is $8.6 \%$.

\begin{tabular}{|} 
If you choose conventional bank. What is the most important reason attracting you to use conventional \\
banking system?
\end{tabular}

Frequency Table 7: In this table we found the which bank provide the batter product and services according the customer wants, they are divided in to three categories. Number one is(conventional bank) their total number is 54 and percentage is $51.4 \%$.and second is (Islamic bank)and their total number of customer is 41 and their percentage is $39.0 \%$. And third is (other specify) their total number is 10 and their percentage is $9.5 \%$.

\begin{tabular}{|c|c|c|c|c|c|}
\hline \multicolumn{2}{|c|}{ Which bank provide you batter product and services according you want? } \\
\hline \multirow{2}{*}{} & Frequency & Percent & Valid Percent & $\begin{array}{c}\text { Cumulative } \\
\text { Percent }\end{array}$ \\
\hline \multirow{3}{*}{ Valid } & conventional bank & 54 & 51.4 & 51.4 & 51.4 \\
\cline { 2 - 6 } & Islamic bank & 41 & 39.0 & 39.0 & 90.5 \\
\cline { 2 - 6 } & Other(specify) & 10 & 9.5 & 9.5 & 100.0 \\
\cline { 2 - 6 } & Total & 105 & 100.0 & 100.0 & \\
\hline
\end{tabular}

Frequency Table 8: In this table we found the which bank customers are preferring in term of profit. They're divided in to three categories number one is (conventional bank) their total number of customer is 48 and their percentage is $45.7 \%$. and second is (Islamic bank) their total number is 44 and their percentage is $41.3 \%$ and third is (other specify) their total number is 13 and their percentage is $12.4 \%$.

\begin{tabular}{|c|c|c|c|c|c|}
\hline \multicolumn{5}{|c|}{ Which bank do you prefer in term of profit? } & $\begin{array}{c}\text { Valid Percent } \\
\text { Percent }\end{array}$ \\
\hline \multirow{2}{*}{} & Frequency & Percent & & 45.7 \\
\hline \multirow{3}{*}{ Valid } & Conventional bank & 48 & 45.7 & 45.7 & 87.6 \\
\cline { 2 - 6 } & Islamic bank & 44 & 41.9 & 41.9 & 100.0 \\
\cline { 2 - 6 } & Other(specify) & 13 & 12.4 & 12.4 & \\
\cline { 2 - 6 } & Total & 105 & 100.0 & 100.0 & \\
\hline
\end{tabular}


Frequency Table 9: In this table we found which factors of motivation that attracts the customer towards the bank they are divided into four categories. Number one is (interest) their total number is 20 and their percentage is $19.0 \%$.and second is (easy to bear loan) their total number is 22 and their percentage is $21.0 \%$.and third is (obtain the fund easily)their total number is 21 and percentage is $20.0 \%$ and number four is (product and services) their total number is 42 and percentage is $40.0 \%$.

\begin{tabular}{|c|c|c|c|c|c|}
\hline \multicolumn{6}{|c|}{ Which factor of motivation attracts you more towards banking system? } \\
\hline \multirow{3}{*}{ Valid } & Frequency & Percent & Valid Percent & Cumulative Percent \\
\cline { 2 - 6 } & Interest & 20 & 19.0 & 19.0 & 19.0 \\
\cline { 2 - 6 } & Easy to bear loan & 22 & 21.0 & 21.0 & 40.0 \\
\cline { 2 - 6 } & Obtain the fund easily & 21 & 20.0 & 20.0 & 60.0 \\
\cline { 2 - 6 } & products and services & 42 & 40.0 & 40.0 & 100.0 \\
\cline { 2 - 6 } & Total & 105 & 100.0 & 100.0 & \\
\hline
\end{tabular}

Frequency Table 10: In this table we found which bank customers are preferred to get loan on the basis of difference interest rate. They are divided in to three categories number one is (Islamic bank) their total number is 42 and their percentage is $40.0 \%$.and second is (conventional bank) their total number is 48 and their percentage is $45.7 \%$.and third is (other specify) their total number is 15 and their percentage is $14.3 \%$.

\begin{tabular}{|c|c|c|c|c|c|}
\hline \multicolumn{6}{|c|}{ On the basis of different interest rates which bank do you prefer to get loan from? } \\
\hline \multirow{3}{*}{ Valid } & Frequency & Percent & Valid Percent & Cumulative Percent \\
\cline { 2 - 6 } & Islamic bank & 42 & 40.0 & 40.0 & 40.0 \\
\cline { 2 - 6 } & Conventional bank & 48 & 45.7 & 45.7 & 85.7 \\
\cline { 2 - 6 } & Other(specify) & 15 & 14.3 & 14.3 & 100.0 \\
\cline { 2 - 6 } & Total & 105 & 100.0 & 100.0 & \\
\hline
\end{tabular}

Frequency Table 11: In this table we found the according to statement which bank customer are mostly preferred. They also divided in to three categories. Number one is (Islamic bank) their total number is 58 and percentage is $55.2 \%$. and no second is (conventional bank) their total no is 39 and their percentage is $37.1 \%$ and third is (other specify) their total number is 8 and their total percentage is $7.6 \%$.

\begin{tabular}{|c|c|c|c|c|c|}
\hline \multicolumn{6}{|c|}{$\begin{array}{l}\text { Conventional bank practices concerned with "elimination of risk "and Islamic bank practices "bear risk" } \\
\text { according that which bank do you select to open a bank account? }\end{array}$} \\
\hline & & Frequency & Percent & Valid Percent & Cumulative Percent \\
\hline \multirow[t]{4}{*}{ Valid } & Islamic bank & 58 & 55.2 & 55.2 & 55.2 \\
\hline & Conventional bank & 39 & 37.1 & 37.1 & 92.4 \\
\hline & Other(specify) & 8 & 7.6 & 7.6 & 100.0 \\
\hline & Total & 105 & 100.0 & 100.0 & \\
\hline
\end{tabular}

Frequency Table 12: In this table we found which bank mostly customer prefer to obtain desire earning while holding the risk level quickly. They are divided in to two categories number one is (Islamic bank) their total number is 41 and their percentage is $39.0 \%$. and number second is (conventional bank) their total number is 64 and their percentage is $61.0 \%$.

\begin{tabular}{|c|c|c|c|c|c|}
\hline \multicolumn{6}{|c|}{ What do you think which bank obtain desired earning while holding the acceptable the risk level quickly? } \\
\hline & & Frequency & Percent & Valid Percent & Cumulative Percent \\
\hline \multirow[t]{3}{*}{ Valid } & Islamic bank & 41 & 39.0 & 39.0 & 39.0 \\
\hline & Conventional bank & 64 & 61.0 & 61.0 & 100.0 \\
\hline & Total & 105 & 100.0 & 100.0 & \\
\hline
\end{tabular}

Frequency Table 13: In this table we found the which bank customer are mostly preferred according to that statement. They are also divided in to two categories. number one is (conventional bank)their total number is 55 and percentage is $52.4 \%$ and number second is (Islamic bank)their total number is 50 and their percentage is $47.6 \%$.

The operating earning margin is limited of conventional bank but higher than Islamic bank according to that which bank do you prefer?

\begin{tabular}{|c|c|c|c|c|c|}
\hline \multirow{2}{*}{ Valid } & Frequency & Percent & Valid Percent & Cumulative Percent \\
\cline { 2 - 6 } & conventional bank & 55 & 52.4 & 52.4 & 52.4 \\
\cline { 2 - 6 } & Islamic bank & 50 & 47.6 & 47.6 & 100.0 \\
\hline
\end{tabular}




\begin{tabular}{|l|l|l|l} 
Total & 105 & 100.0 & 100.0
\end{tabular}

Frequency Table 14: In this table we found which banking system customer satisfaction is high. They are divided in to two categories number one is (conventional bank )their total number is 59 and their percentage is 56.2 and number second is (Islamic bank)their total number is 46 and their total percentage is $43.8 \%$.

\begin{tabular}{|c|c|c|c|c|c|}
\hline \multicolumn{6}{|c|}{ In which banking system the level of your satisfaction is high? } \\
\hline \multirow{3}{*}{ Valid } & Frequency & Percent & Valid Percent & Cumulative Percent \\
\cline { 2 - 6 } & conventional bank & 59 & 56.2 & 56.2 & 56.2 \\
\cline { 2 - 6 } & Islamic bank & 46 & 43.8 & 43.8 & 100.0 \\
\cline { 2 - 6 } & Total & 105 & 100.0 & 100.0 & \\
\end{tabular}

\section{Conclusion:-}

Most of the customers, either form Islamic or conventional are satisfied with the products and services offered by the banks in Hyderabad. However, the customers of conventional banks were found to be more satisfied as compared to the customers of Islamic banks. Despite the vigorous campaign of Islamic banks with their slogan of Shariah compliance, this study found that interest on deposits, good product and policies were the factors that were motivating customers towards conventional banks. Whereas, factors that attract customers towards Islamic banks are; Islamic teaching and Shariah. However, there is number clear preference shown by customers for either conventional or Islamic banks.

\section{Recommendations:-}

Islamic bank can capture more customers by focusing more on effective marketing campaigns for augmenting public awareness towards quality of their services. They can increase their customer ship by introducing promising and satisfactory products and services. As their purpose of Shariah compliance can be achieved. Their objectives can be achieved through quality initiatives for improving their products and services by the managers of the banks.

\section{References:-}

1. Asdullah, M. A., \& Yazdifar, H. (2016). Evaluation of factors influencing youth towards Islamic banking in Pakistan. ICTACT Journal on Management Studies, 2(1).

2. Beck, T., Demirgüç-Kunt, A., \& Merrouche, O. (2013). Islamic vs. conventional banking: Business model, efficiency and stability. Journal of Banking \& Finance, 37(2), 433-447.

3. Erol, C., F. Baklaci, H., Aydoğan, B., \& Tunç, G. (2014). Performance comparison of Islamic (participation) banks and commercial banks in Turkish banking sector. EuroMed Journal of Business, 9(2), 114-128.

4. Khan, M. S. N., Hassan, M. K., \& Shahid, A. I. (2008). Banking behavior of Islamic bank customers in Bangladesh. Journal of Islamic Economics, Banking and Finance, 3(2), 159-194.

5. Latif, Y., Abbas, A., Akram, M. N., Manzoor, S., \& Ahmad, S. (2016). Study of Performance comparison Between Islamic and Conventional Banking In Pakistan. European Journal of Educational and Development Psychology, 4(1), 17-33.

6. Mohsin Butt, M., \& Aftab, M. (2013). Incorporating attitude towards Halal banking in an integrated) service quality, satisfaction, trust and loyalty model in online Islamic banking context. International Journal of Bank Marketing, 31(1), 6-23.

7. Rammal, H. G., \& Parker, L. D. (2013). Islamic banking in Pakistan: A history of emergent accountability and regulation. Accounting History, 18(1), 5-29.

8. Riaz, Ahsan, R. Awad, and S. Nadia. "Customer satisfaction between Islamic and conventional banks: Case of Pakistan." Social and basic sciences research review 1.2 (2014): 69-73.

9. Siddiqi, M. N. (2006). Islamic banking and finance in theory and practice: A survey of state of the art. Islamic economic studies, 13(2), 1-48.

10. Yousefi, M., Abizadeh, S., \& McCormick, K. (1997). Monetary stability and interest-free banking: the case of Iran. Applied Economics, 29(7), 869-876.

11. Zaher, T. S., \& Kabir Hassan, M. (2001). A comparative literature survey of Islamic finance and banking. Financial Markets, Institutions \& Instruments, 10(4), 155-199. 